\title{
Chemistry and applications of benzonaphthyridines
}

\author{
Barbara Bachowska * and Teresa Zujewska \\ Institute of Chemistry and Environment Protection, Pedagogical University, \\ PL 42-201 Częstochowa, Poland \\ E-mail: b.bachowska@wsp.czest.pl
}

Dedicated to Prof. Rudy Abramovich on the occasion of his $\mathbf{7 0}^{\text {th }}$ birthday (received 12 Apr 01; accepted 01 Oct 01; published on the web 09 Oct 01)

\begin{abstract}
Cycloadditions of benzonaphthyridines, their N-oxides and ylides from their quaternary salts are presented. Dimethylacetylenedicarboxylate, diethyl maleate, acrylonitrile and others were used as dipolarophiles. Cyclization of $\mathrm{N}$-phenacylbenzonaphthyridinium bromides with ammonium acetate as well as vicarious substitution of hydrogen of benzonaphthyridine $\mathrm{N}$-oxides are also reported and pathways to their formation are proposed.
\end{abstract}

Keywords: Benzonaphthyridines, benzonaphthyridiene N-oxides, benzonaphthyridine ylides cycloaddition reactions

\section{Introduction}

Isomeric benzo[c][1,5]-, benzo[h][1,6]- and benzo[f][1,7]naphthyridines $\mathbf{1}-\mathbf{3}$, the theme of our research, are interesting for their chemical reactivity, biological properties, and applications. They exhibit a wide spectrum of biological activity such as bactericidal, fungicidal, and cancerostatic. $^{1-3}$ They are also interesting ligands of the Werner-type $\sigma$-complexes with metal central atoms as well as EDA $\pi$-complexes. ${ }^{4}$

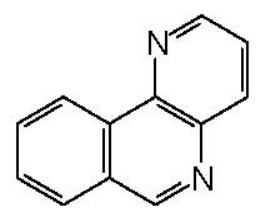

1

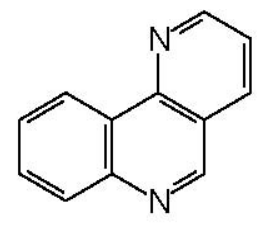

2<smiles>c1ccc2c(c1)ncc1ncccc12</smiles>

3

This brief review covers our contribution to the knowledge of reactivity of benzonaphthyridines 1 - 3. We present their N-oxidation, quaternization and cycloadditions of unsubstituted systems, as well as their ylides and $\mathrm{N}$-oxides. We also report cyclization of a series 
of the quaternary $\mathrm{N}$-phenacylbenzonaphthyridinium bromides with ammonium acetate into tetracyclic benzoimidazonaphthyridines as well as vicarious nucleophilic substitution of hydrogen and formation of aziridine derivatives in reactions of benzonaphthyridines and their Noxides with carbanions.

\section{Formation of benzonaphthyridinium salts and cycloaddition reactions}

The 1,3-dipolar cycloaddition of ylides 4 - 6 derived from benzonaphthyridines $\mathbf{1}$ - 3, i.e. to phenacylides, ${ }^{5-7}$ ethoxycarbonylmethylides ${ }^{8-11}$ and dichloromethylides ${ }^{12}$ offer a convenient route to tetracyclic compounds.
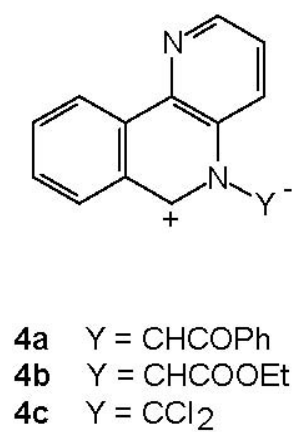<smiles>[Y]n1[cH+]c2cccnc2c2ccccc21</smiles>

5a $\mathrm{Y}=\mathrm{CHCOPh}$

5b $\mathrm{Y}=\mathrm{CHCOOEt}$ 5c $\quad \mathrm{Y}=\mathrm{CCl}_{2}$<smiles>[Y]N1[C+]c2ncccc2-c2ccccc21</smiles>

6a $Y=\mathrm{CHCOPh}$

6b $Y=\mathrm{CHCOOEt}$

6c $\mathrm{Y}=\mathrm{CCl}_{2}$

Quaternary bromides, 7a,b - 9a,b, were precursors of ylides, 4a,b - 6a,b.<smiles>[Z][n+]1cc2ccccc2c2ncccc21</smiles>

7a $\mathrm{Z}=\mathrm{CH}_{2} \mathrm{COPh}$ 7b $\mathrm{Z}=\mathrm{CH}_{2} \mathrm{COOEt}$<smiles>[Z][n+]1cc2cccnc2c2ccccc21</smiles>

$8 \mathrm{a} \quad \mathrm{Z}=\mathrm{CH}_{2} \mathrm{COPh}$ 8b $\mathrm{Z}=\mathrm{CH}_{2} \mathrm{COOEt}$<smiles>[Z][n+]1cc2ncccc2c2ccccc21</smiles>

9a $\mathrm{Z}=\mathrm{CH}_{2} \mathrm{COPh}$

9b $\mathrm{Z}=\mathrm{CH}_{2} \mathrm{COOE}$

The benzonaphthyridinium salts 7a,b - 9a,b were obtained by quaternization of $\mathbf{1}$ - $\mathbf{3}$ with phenacyl bromide or ethyl bromoacetate. The quaternary salts reacted with $\mathrm{Et}_{3} \mathrm{~N}$ into corresponding ylides 4a,b - 6a,b. The latter reacted in situ with one of the following dipolarophiles: acrylonitrile, ethyl acrylate, dimethylacetylenedicarboxylate, maleic anhydride, diethyl maleate, methyl vinyl ketone, acrylic and methacrylic acid. In this manner tetracyclic substituted cycloadducts benzopyrrolo-, benzopyrroline- or benzopyrrolidine-naphthyridines were obtained (Scheme 1).

Scheme 1 shows a pathway of 1,3-dipolar cycloaddition of benzo[c][1,5]-naphthyridinium Nphenacylide to a series of dipolarophiles. Similar pathways were proposed for cyclizations with benzo[h][1,6]naphthyridinium phenacylide, ${ }^{5,6}$ as well as benzo[c][1,5]-, benzo[h][1,6]- and benzo[f][1,7]naphthyridinium carboethoxymethylides. ${ }^{8-11}$ 
<smiles>C=CCCCCCC(=O)O</smiles>

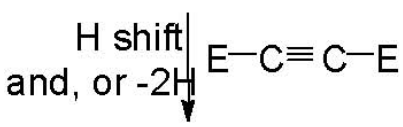<smiles>[Z]C1[C@H]([Z])[C@@H](C(=O)O)N2c3cccnc3-c3ccccc3[C@H]12</smiles><smiles>CC(=O)c1c(F)c(C(=O)O)n2c3cccnc3c3ccccc3c12</smiles>

\section{Scheme 1}

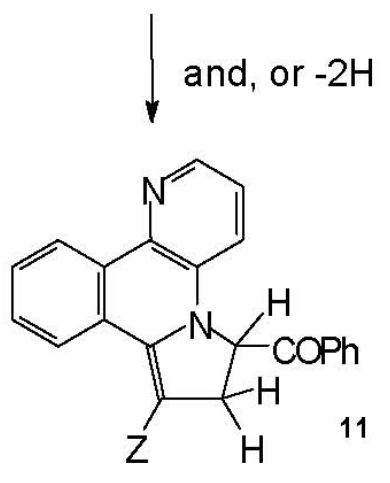

$\mathrm{Z}=\mathrm{CN}, \mathrm{COMe}, \mathrm{COOEt}, \mathrm{COOH}$

N-dichloromethylides 4c - 6c were formed in situ from benzonaphthyridines $\mathbf{1}$ - $\mathbf{3}$ and dichlorocarbene thermally generated from sodium trichloroacetate in chloroform in the presence of benzyltriethylammonium chloride (TEBA). The 1,3-dipolar cycloaddition of Ndichloromethylides $\mathbf{4 c}$ - 6c with dimethyl acetylenedicarboxylate (DMAD) as dipolarophile produced compounds of the type $\mathrm{C}$ (Scheme 2$)^{12}$.

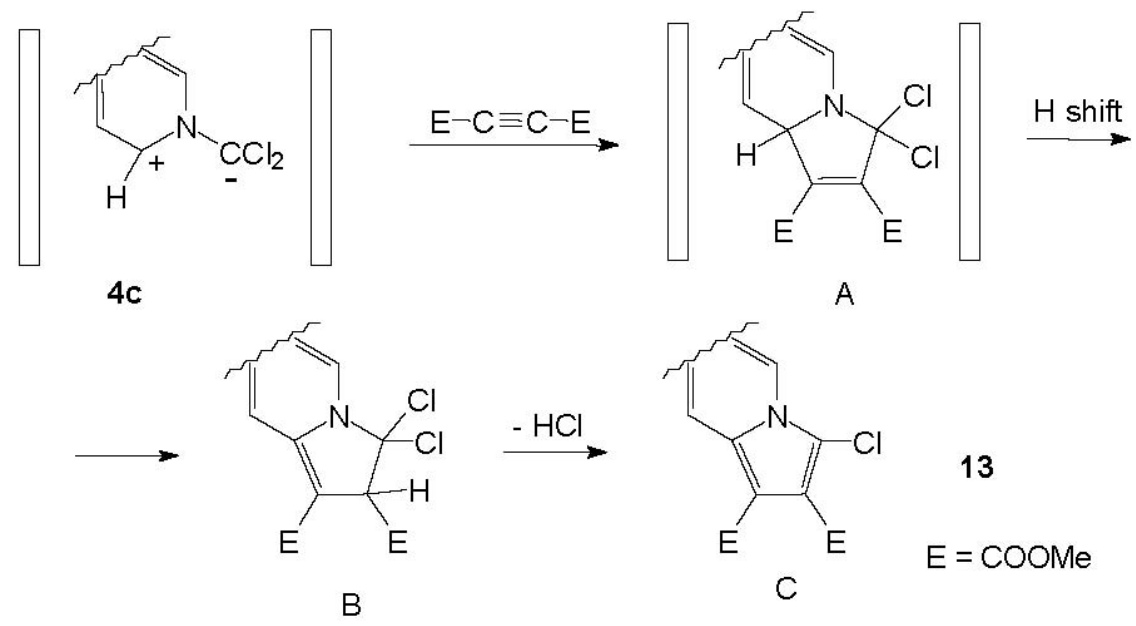

\section{Scheme 2}

Compounds 14 and 15, which were formed as minor products of the above reactions ${ }^{12}$ present examples of cycloadducts of unsubstituted benzonaphthiridine systems to acetylenedicarboxylate. Cycloadduct 15 constituted a main product in the cycloaddition of 
benzo[f][1,7]naphthyridine to DMAD carried out at room temperature in benzene solution. ${ }^{11}$<smiles>FC1=C(F)C(F)C(F)(F)N2C(F)=C1c1cccnc1-c1ccccc12</smiles><smiles></smiles>

${ }^{1} \mathrm{H}$ NMR as well as mass spectra of cycloadducts of benzo[c][1,5]-, benzo[h][1,6]naphthyridinium phenacylides and benzo[c][1,5]-, benzo[h][1,6]-naphthyridinium ethoxycarbonylmethylides with a series of dipolarophiles were determined and discussed in separate papers. ${ }^{13-16}{ }^{1} \mathrm{H}$ NMR spectra of cycloadducts were compared with those of parent benzonaphthyridines; all observed shifts were explained by electronic and steric features.

\section{Synthesis of benzoimidazonaphthyridines}

Cyclization of a series of the quaternary N-phenacylbenzonaphthyridinium bromides 7a - 9a with ammonium acetate in the presence of ferric chloride in acetic acid provided tetracyclic fused imidazole derivatives such as 2-phenylbenzo[c]-imidazo[1,2-a][1,5]naphthyridine 16, 2phenylbenzo[h]imidazo[2,1-f][1,6]naphthyridine $\quad 17$, and 2-phenylbenzo[f]imidazo[1,2h][1,7]naphthyridine 18 (Scheme 3). ${ }^{17}$<smiles>Brc1ccccc1</smiles>

$7 a$<smiles></smiles>

$8 \mathrm{a}$

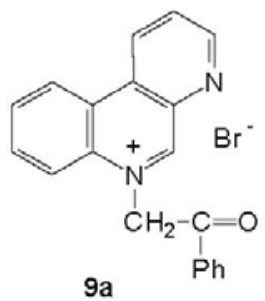

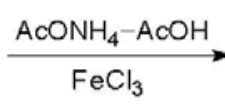

h
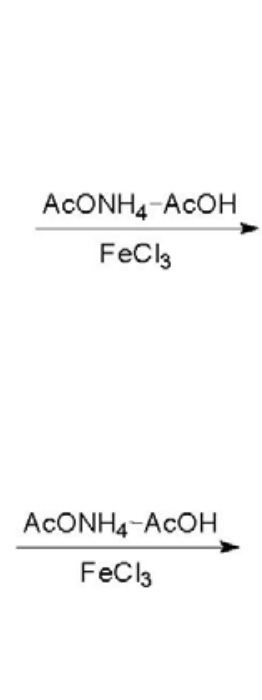
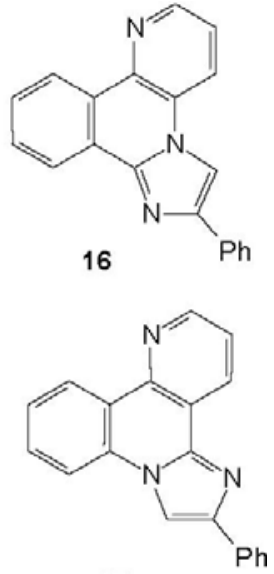

17

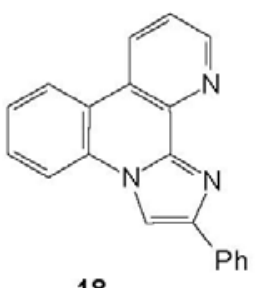

18

\section{Scheme 3}

It should be mentioned that analogous arylimidazo[2,1-a]isoquinolines were shown to exhibit 
pregnancy terminating activity in both hamsters and rats. ${ }^{18}$ We anticipate similar interesting applications for above imidazole derivatives.

\section{Benzonaphthyridine $N$-oxides as 1,3-dipoles}<smiles>[O-][n+]1cc2ccccc2c2ncccc21</smiles>

19

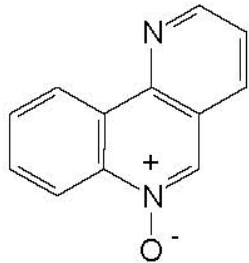

20<smiles>[O-][n+]1cc2ncccc2c2ccccc21</smiles>

21<smiles>[O-][n+]1cccc2c3ccccc3[n+]([O-])cc21</smiles>

22

Benzo[c][1,5]naphthyridine-5-oxide 19, benzo[h][1,6]naphthyridine-6-oxide 20, benzo[f][1,7]naphthyridine-6-oxide 21, and benzo[f][1,7]naphthyridine-4,6-dioxide 22 reacted with such dipolarophiles as dimethyl acetylenedicarboxylate, ethyl propiolate and ethyl phenylpropiolate to give the ylides ${ }^{19,20}$ (Scheme 4$)$.

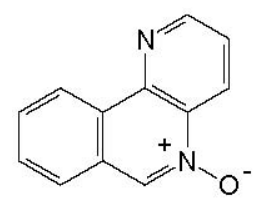

19

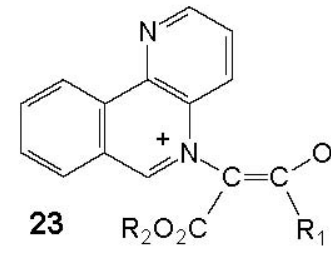

$\mathrm{R}_{1}=\mathrm{H}, \mathrm{Ph},-\mathrm{OCOCH}_{3}$

$\mathrm{R}_{2}=\mathrm{CH}_{3}, \mathrm{C}_{2} \mathrm{H}_{5}$

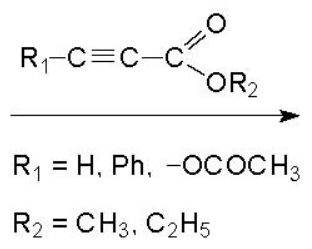

$\mathrm{R}_{2}=\mathrm{CH}_{3}, \mathrm{C}_{2} \mathrm{H}_{5}$

\section{Scheme 4}

Scheme 4 illustrates a pathway for the formation of ylides. Initial 1,3-dipolar cycloaddition was followed by the ring contraction to aziridine derivative and the ring opening.

Reaction of 19 with phenyl isocyanate, carried out at room temperature (DMF), led to carbamic acid derivative 24. Decarboxylation of 24 induced by heating at $150^{\circ} \mathrm{C}$ in $\mathrm{DMF}$ resulted in the formation of 6-anilino-benzo[c][1,5]naphthyridine 25 . N-Oxides 20 and 21 reacted with phenyl isocyanate at $150^{\circ} \mathrm{C}$ in DMF into 5-anilino-benzo[h][1,6]naphthyridine 26 and 5-anilino-benzo[f][1,7]naphthyridine 27 respectively (Scheme 5). Dioxide 22 failed to react at room temperature as well as at $150^{\circ} \mathrm{C}$, possibly for steric reasons. ${ }^{21}$ 

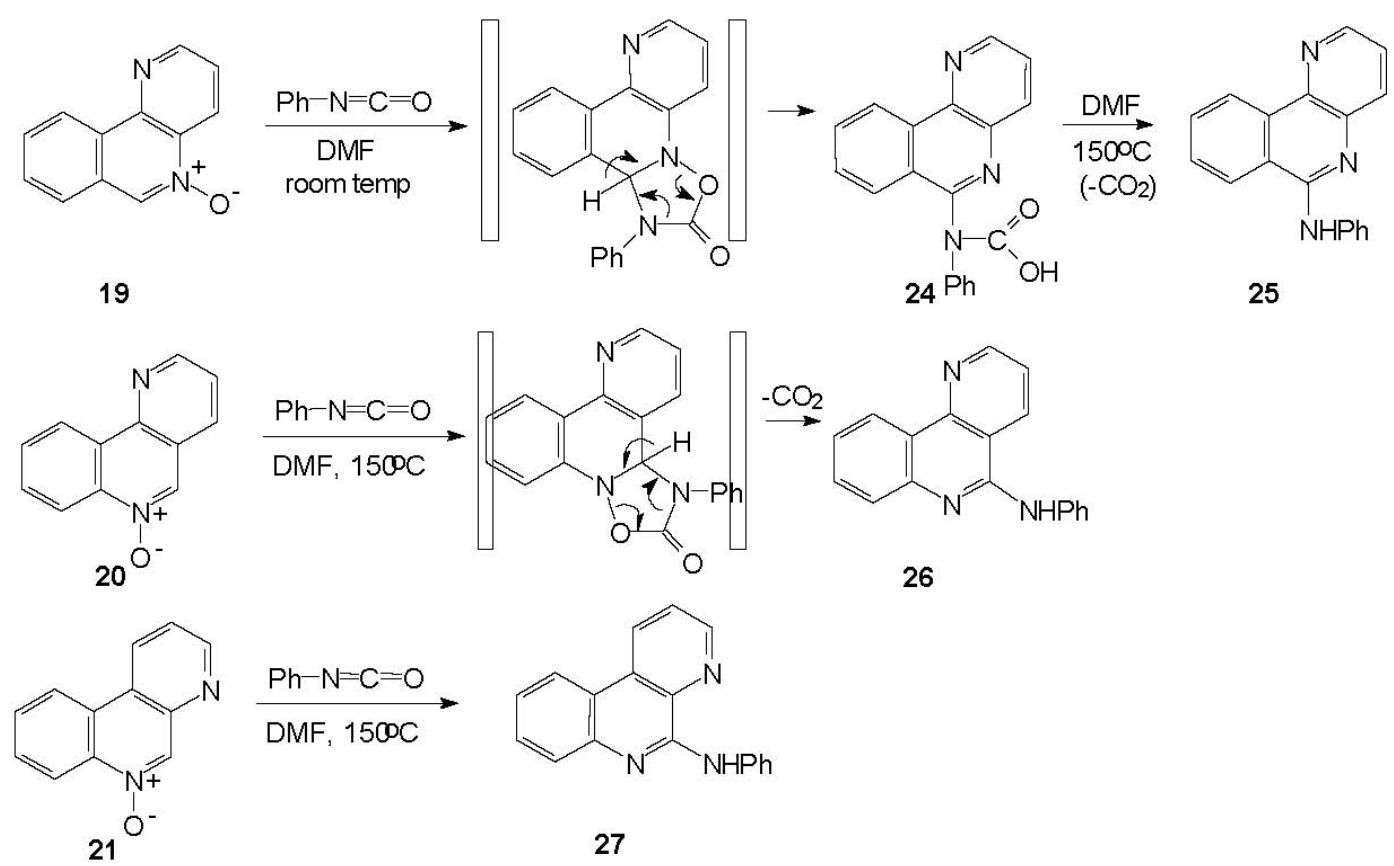

26

\section{Scheme 5}

Proposed pathway of these reactions comprises of initial 1,3-dipolar cycloaddition of phenyl isocyanate to benzonaphthyridine $\mathrm{N}$-oxides followed by aromatization and decarboxylation. Our results and proposed mechanisms of the investigated reactions as shown in Schemes 4 and 5 are in accordance with literature data for similar 1,3-dipolar cycloaddition reactions of azaaromatic $\mathrm{N}$-oxides with activated acetylenes and phenyl isocyanate. ${ }^{22}$

\section{Vicarious nucleophilic substitution of hydrogen in the chemistry of benzonaphthyridines}

Vicarious nucleophilic substitution of hydrogen (VNS) offered a facile procedure for the introduction of substituents into electrophilic aromatic rings. The VNS is a general reaction between carbanions containing a leaving group $\mathrm{X}$ and a variety of electrophilic aromatic and heteroaromatic compounds. Examples of such carbanions precursors are $\mathrm{ClCH}_{2} \mathrm{SO}_{2} \mathrm{Ph}$, $\mathrm{ClCH}_{2} \mathrm{COR}, \mathrm{Cl}_{2} \mathrm{CHCO}_{2} \mathrm{R}, \mathrm{PhOCH}_{2} \mathrm{CN}$ and $\mathrm{CH}_{2}(\mathrm{SPh})_{2}$. VNS proceeded via addition of the carbanions to the electrophilic aromatic compounds resulting in the formation of anionic $\sigma$ adducts. Base-induced $\beta$-elimination of $\mathrm{HX}$ followed by protonation gave products of the substitution ${ }^{23}$ (Scheme 6).

\section{Scheme 6}

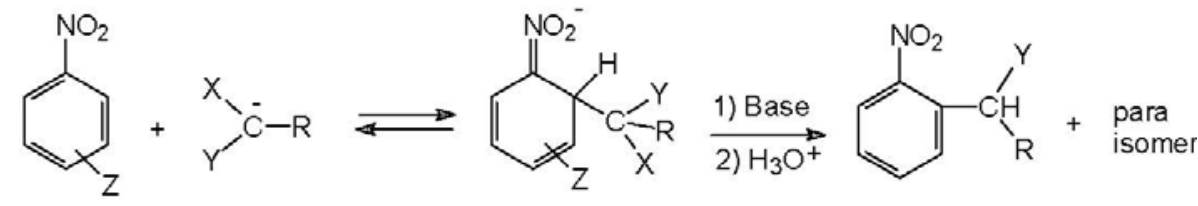

Application of these reactions to benzonaphthyridines and their N-oxides was proven. Reactions of benzo[c][1,5]-, benzo[h][1,6]- and benzo[f][1,7]naphthyridines $\mathbf{1}$ - $\mathbf{3}$ and of their N- 
oxides 19 - 22 with chloromethyl phenyl sulfone as the carbanion precursor were carried out at room temperature using $\mathrm{KOH}$ suspended in DMSO as a base. ${ }^{24}$ The proposed pathway for such kind reactions of benzo[c][1,5]naphthyridine $\mathbf{1}$ and benzo[c][1,5]naphthyridine-5-oxide $\mathbf{1 9}$ are presented in Scheme 7.
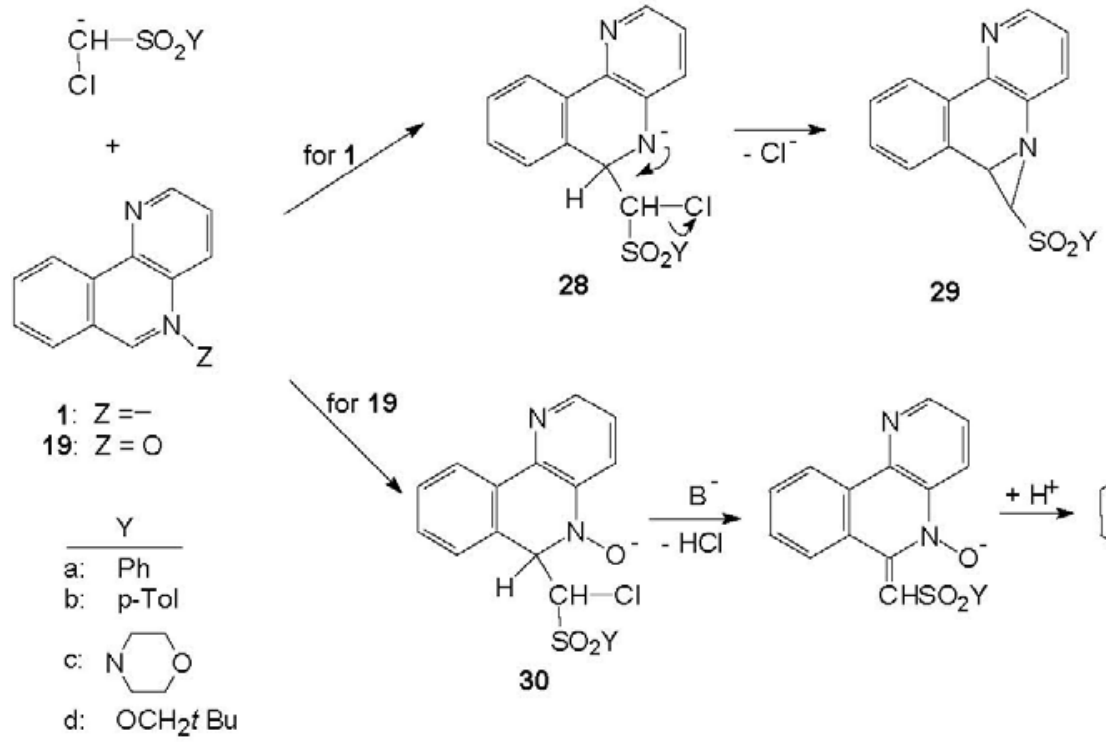

29

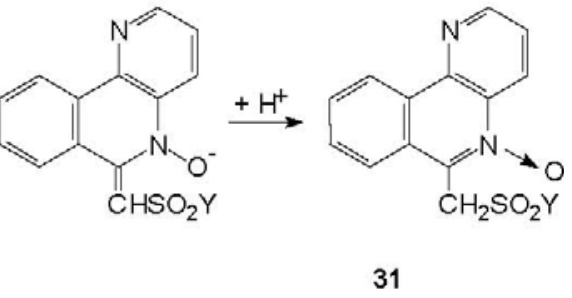

Scheme 7

Extensive charge delocalization in the anionic $\sigma$-adduct of the carbanion with benzonaphthyridine $\mathrm{N}$-oxide 30 caused by the strong electron accepting oxygen atom, favoured base-induced $\beta$-elimination resulting in the formation of 6-benzenesulfonylmethyl-benzo[c][1,5]naphthyridine-5-oxide 31a as the VNS product. However, in the $\sigma$-adduct with benzonaphthyridine $\mathbf{2 8}$ the negative charge was localized chiefly on the vicinal nitrogen atom, which behaved as a strong nucleophilic center and underwent fast intramolecular substitution leading to the annelation product, the aziridine derivative, 6-benzenesulfonyl-aziridine[1,2a]benzo[c]-[1,5]naphthyridine 29a. The same reactions with benzo[h][1,6]-, benzo[f][1,7]naphthyridines, their 6-oxides and with benzo[f][1,7]-naphthyridine-4,6-dioxide were also investigated. They proceeded in acordance with literature data for some electrophilic bicyclic azines such as quinoxalines ${ }^{25}$ and quinoxaline-1-oxide. ${ }^{26}$

Satisfactory results were available also with chloromethyl $p$-tolyl sulfone, bromo- and chloromethanesulfomorpholide and neopentyl chloromethanesulfonate as carbanion precursors ${ }^{27}$.

\section{Acknowledgements}

Authors Barbara Bachowska (post doc. at Clemson University 1984/85) and Teresa Zujewska (maiden name Radzikowska; graduate student at University of Alabama 1975-77) are grateful to Prof. R.A. Abramovich for excellent training in his research group and 26 years of his cooperation and help. 


\section{References}

1. Sliwa, W. Studies on Benzo[h]naphthyridines; Scientific Papers of the Institute of Organic and Physical Chemistry, No. 13/8. Wrocław Technical University, Wrocław 1978.

2. Matusiak, G.; Śliwa, W. Acta Chim. Hung. 1988, 125, 267.

3. Chrząstek, L.; Mianowska, B.; Śliwa, W. Aust. J. Chem. 1994, 47, 2129.

4. Zelichowicz, N.; Gaudyn, A. Chem. Papers 1992, 46, 284.

5. Bachowska, B.; Śliwa, W. Monatsh. Chem. 1984, 115, 1101.

6. Bachowska, B.; Śliwa, W. Acta Chim. Hung. 1988, 125, 491.

7. Matusiak, G.; Śliwa, W. Monatsh. Chem. 1993, 124, 161.

8. Radzikowska, T.; Śliwa, W. J. Prakt. Chem. 1985, 327, 689.

9. Radzikowska, T.; Śliwa, W. J. Prakt. Chem. 1987, 329, 529.

10. Girek, T.; Zujewska, T.; Śliwa, W. Acta Chim. Hung. 1990, 127, 711.

11. Bachowska, B.; Zujewska, T. Polish J. Chem. 1996, 70, 1324.

12. Bachowska, B. Monatsh. Chem. 1995, 126, 227.

13. Śliwa, W.; Bachowska, B.; Postawka, A. Magn. Res. in Chemistry 1991, 29, 1070.

14. Bachowska, B.; Śliwa, W. Chem. Papers 1991, 45(3), 349.

15. Zujewska, T.; Śliwa, W. Chemistry of Heterocyclic Compounds Studies in Organic Chemistry; Elsevier: Amsterdam, 1988; Vol. 35; 588.

16. Zujewska, T. Prace Naukowe Wyższej Szkoły Pedagogicznej w Częstochowie (Pedagogical University Issues), Chemia I 1997, 145.

17. Bachowska, B.; Zujewska, T. Aust. J. Chem. 2001, 54, 89.

18. Toja, E.; Omodei-Sale', A.; Favara, D.; Cattaneo, C.; Gallico, L.; Galliani, G. ArzneimForsch / Drug Res. 1983, 33(II), 1222.

19. Zujewska, T.; Bachowska, B. Aust. J. Chem. 1996, 49, 523.

20. Zujewska, T.; Bachowska, B. Polish J. Chem. 1998, 72, 2507.

21. Bachowska, B.; Zujewska, T. Polish J. Chem. 1998, 72, 89.

22. Abramovitch, R.A.; Shinkai, I. Acc. Chem. Res. 1976, 9, 192.

23. Mąkosza, M.; Goliński, J.; Ostrowski, S.; Rykowski, A.; Sahasrabudhe, A.B. Chem. Ber. 1991, 124, 577.

24. Bachowska, B.; Zujewska, T. Monatsh. Chem. 2001, 132, 849.

25. Goliński, J.; Mąkosza, M.; Rykowski, A. Tetrahedron Lett. 1983, 3279.

26. Mąkosza, M.; Glinka, T.; Ostrowski, S.; Rykowski, A. Chem. Lett. 1987, 61.

27. Bachowska, B.; Zujewska, T. unpublished results. 